\title{
Heavy metals health risk assessment for population via consumption of vegetables grown in old mining area; a case study: Banat County, Romania
}

\author{
Monica Harmanescu, Liana Maria Alda, Despina Maria Bordean, loan Gogoasa and losif Gergen*
}

\begin{abstract}
Background: The aim of this study is to measure the levels of heavy metals ( $\mathrm{Fe}, \mathrm{Mn}, \mathrm{Zn}, \mathrm{Cu}, \mathrm{Ni}, \mathrm{Cd}$ and $\mathrm{Pb}$ ) found in common vegetables (parsley, carrot, onion, lettuce, cucumber and green beans) grown in contaminated mining areas compared with those grown in reference clear area and to determine their potential detrimental effects via calculation of the daily metal intake (DImetal) and Target Hazard Quotients (THQ) for normal daily consumption of these vegetables, for male and female gender.

Results: Compared with the reference in contaminated areas, soil and plant contents of all analyzed metals are higher, usually over normally content for $\mathrm{Mn}, \mathrm{Zn}, \mathrm{Cu}, \mathrm{Cd}$ and Pb. Particularly, in soil, higher values than intervention threshold values (ITV) were found for $\mathrm{Cu}$ and $\mathrm{Pb}$ and higher than maximum allowable limits (MAL) for $\mathrm{Zn}, \mathrm{Cu}, \mathrm{Cd}$ and $\mathrm{Pb}$ for parsley roots and leaves, carrot roots, cabbage, lettuce and cucumber. DImetal and THQ values for male and female were calculated for each vegetable and metal and for which oral reference doses exist. The combined $T H Q$ values calculated are concerning in that they are usually below the safe level of $T H Q<1$ for all vegetables grown in reference area. In contaminated Moldova Noua (M) area the combined THQ exceeded the safe level only for parsley roots, while in more contaminated Ruschita (R) area combined THQ exceeded the safe level for parsley and carrot roots, lettuce and cabbage. $\mathrm{Cd}$ and $\mathrm{Pb}$, most toxic metals to humans, have an increasing prevalence in the combined THQ for leafy (cabbage and lettuce) and fruit vegetables (cucumber). In the root vegetables only $\mathrm{Pb}$ has an increasing prevalence in combined THQ values. In all areas female THQ is higher than male THQ.

Conclusion: The results of this study regarding metal contents in soils, vegetables, DImetal and THQ suggest that the consumption of some vegetables (especially parsley, carrot and cabbage and less for lettuce, cucumber and green beans) is not free of risks in these areas. The complex THQ parameter use in health risk assessment of heavy metals provides a better image than using only a simple parameter (contents of metals in soils and vegetables).
\end{abstract}

\section{Background}

Heavy metals are ubiquitous in the environment, as a result of both natural and anthropogenic activities, and humans are exposed to them through various pathways, especially food chain. The essentiality of $\mathrm{Fe}, \mathrm{Mn}, \mathrm{Cu}$ and $\mathrm{Zn}$ are based on their role as metalloenzymes. These metals are cofactor of large number of enzymes [1]. For these essential metals there is a range of intake over

\footnotetext{
* Correspondence: igergen@yahoo.com

Banat's University of Agricultural Sciences and Veterinary Medicine, Calea Aradului 119, RO 300645, Timisoara, Romania
}

which their supply is adequate to the body (Fe 8-18 $\mathrm{mg} /$ day, $\mathrm{Mn} 1.8-2.3 \mathrm{mg} /$ day, $\mathrm{Cu} 0.9 \mathrm{mg} /$ day, $\mathrm{Zn} 8-11 \mathrm{mg} /$ day, Ni $0.5 \mathrm{mg} /$ day) $[1,2]$. However, beyond this ranges, deficiency and toxic effects are observed [1,2]. A high supplementation of Fe and Mn causes pathological events such as the iron oxides deposition in Parkinson's disease $[1,3]$. $\mathrm{Cu}$ surplus had been associated with liver damage and $\mathrm{Zn}$ may produce adverse nutrient interactions with $\mathrm{Cu}$. Also, $\mathrm{Zn}$ reduces immune function and the levels of high density lipoproteins [1]. Other metals like $\mathrm{Pb}$ and $\mathrm{Cd}$ are toxic even at low concentration [4]. $\mathrm{Pb}$ is known to induce renal tumours, reduce cognitive 
development, and increase blood pressure and cardiovascular diseases risk for adults and $\mathrm{Cd}$ may induce kidney dysfunctions, osteomalacia and reproductive deficiencies $[1,5]$. As essential part of food, vegetables are important source of these metals. Waste water irrigation, solid waste disposal, sludge applications, vehicular exhaust and industrial activities are the major sources of soil contamination with heavy metals. An increased metal uptake by food crops, vegetables and fruits grown on such contaminated soils is often observed in wide world [6-16]. Vegetables cultivated in contaminated soils take up heavy metals in large quantities enough to cause potential health risks to the consumers $[7-10,12]$. In order to assess the health risks, it is necessary to identify the potential of a source to introduce risk agents into the environment, to estimate the amount of risk agents that come into contact with the human-environment boundaries, and quantify the health consequence of the exposure [6]. Carpathian Mountains represent a rich source of heavy metals for East European countries and these resources were intensively exploited for hundred years. Romania was no exception to this intensive exploitation of mineral resources [17]. Although currently the exploitation of these mineral resources has been reduced or even abandoned, soil contamination with heavy metals remained. The soil and plant contamination with heavy metals is well proven in various studies, especially in North and Central part of Romania [11-16], and less in the South West part [18]. Also in these researches has been less studied the effects of the heavy metals contamination on human health. Our study was conducted to understand the appropriateness of contaminated soils from old mining area, for vegetable cultivation, to assess the metal uptake in vegetables and the potential health risks associated with human consumption of these vegetables contaminated with heavy metals. For that, have been assessed the levels of heavy metals in soil and common vegetables grown in two old mining areas in comparison with reference non polluted area. In total, the levels of seven potential toxic or toxic metals ( $\mathrm{Fe}, \mathrm{Mn}, \mathrm{Zn}, \mathrm{Cu}, \mathrm{Ni}, \mathrm{Cd}$ and $\mathrm{Pb}$ ) have been assessed by flame atomic absorption spectrometry (FAAS) for common vegetables (parsley, carrot, onion, lettuce, cucumber and green beans) especially consumed in these areas. These data were used to calculate the daily intake of metals (DImetal) and target hazard quotients (THQ) values for all metals separately for females and males. Contributions to the THQ value were calculated for seven metals along with total values for each vegetable. Target hazard quotients were developed by the Environmental Protection Agency (EPA) in the US for the estimation of potential health risks associated with long term exposure to chemical pollutants [19]. This includes not only intake of metals but another significant data as exposure frequency and duration, body weight and the oral reference dose (RfD). The THQ is a ratio between the measured concentration and the oral reference dose (RfD), weighted by the length and frequency of exposure, amount ingested and body weight. The THQ $<1$ means the exposed population is assumed to be safe and $1<\mathrm{THQ}<5$ means that the exposed population is in a level of concern interval. THQ parameter is a dimensionless index and THQ values are additive, but not multiplicative. It must be noted that THQ is not a measure of risk but indicates a level of concern. Owing to differences in average weight and lifespan, the THQ values are raised for females [20-23].

\section{Results and discussion}

Levels of heavy metals in soils from contaminated and reference areas

Investigated contaminated areas, Ruschita ( $R$ ) and Moldova Noua (M), are well known for its complex poly metallic ores, lead respectively copper extraction and processing industry in Banat County, South West part of Romania. As reference area was selected Borlova village, well known for ecological agricultural practices. The city/village development has occurred on natural soils as Alluvial Soils and Brown Redish types. By anthropic action, these natural soils have becoming urban soils as Urbic Regosols, Regosols and Mixic Entiantrosols [11-13]. The levels of soil heavy metals from these areas are presented in Table 1.

Iron is the abundant metal, followed by manganese and zinc. In contaminated areas ( $R, M)$ these three metals have the higher contents compared with the reference area. For manganese, in all sites were founded high contents, which exceeded normal contents (NC) and alert threshold values

(ATV) [15]. In $\mathrm{R}$ area manganese content exceeded even intervention threshold values (ITV) and zinc content exceeded ATV. Copper, nickel and lead have the same range of contents in the reference area. In the contaminated area, significant difference appears for both contents of copper and lead. So, copper contents are higher in $M$ area (exceeded ITV) and lead content is higher in R area (exceeded ITV), in concordance with geogenic abundance and anthropogenic activity.

\section{Levels of heavy metals in vegetables from contaminated and reference areas}

Heavy metal concentrations varied among different vegetables (Tables 2, 3 and 4), which may be attributed to differential absorption capacity of vegetables for different heavy metals [7]. All the heavy metals concentrations were several folds higher in the vegetables from 
Table 1 Levels of soil heavy metals from investigated areas $\left(\mathrm{mgKg}^{-1},{ }^{*} \mathbf{p}<0.05\right)$

\begin{tabular}{|c|c|c|c|c|c|c|c|}
\hline Area/Metal contents & $\mathrm{Fe}$ & $\mathrm{Mn}$ & $\mathrm{Zn}$ & $\mathrm{Cu}$ & $\mathrm{Ni}$ & $\mathrm{Cd}$ & $\mathrm{Pb}$ \\
\hline R Area & $55489.20^{*}$ & 5737.71* & $359.33^{*}$ & $47.83^{*}$ & $14.29^{*}$ & $2.00 *$ & $130.10^{*}$ \\
\hline Standard Deviation & 1090.07 & 402.07 & 16.76 & 3.02 & 0.48 & 0.23 & 4.37 \\
\hline M Area & $44582.45^{*}$ & 1845.28 & $197.03^{*}$ & $229.15^{*}$ & $18.40^{*}$ & $0.40 *$ & $22.02^{*}$ \\
\hline Standard Deviation & 429.50 & 75.69 & 7.61 & 10.27 & 0.40 & 0.02 & 0.85 \\
\hline Ref Area & 32774.91 & 2117.80 & 136.26 & 23.94 & 11.12 & 0.17 & 16.76 \\
\hline Standard Deviation & 562.62 & 197.96 & 5.64 & 1.35 & 0.40 & 0.01 & 0.63 \\
\hline $\begin{array}{l}\text { Normal contents, } \\
\text { for Romania (NC) }\end{array}$ & - & 900 & 100 & 20 & 20 & 1 & 20 \\
\hline $\begin{array}{l}\text { Alert threshold values } \\
\text { for Romania (ATV) }\end{array}$ & - & 1500 & 300 & 100 & 75 & 3 & 50 \\
\hline $\begin{array}{l}\text { Intervention threshold } \\
\text { Values for Romania (ITV) }\end{array}$ & - & 2500 & 600 & 200 & 150 & 5 & 100 \\
\hline
\end{tabular}

contaminated area ( $\mathrm{R}$ and $\mathrm{M}$ sites) as compared to uncontaminated area (Ref site).

The most abundant element in parsley and carrot roots and onion was Fe for both reference and contaminated soils (Table 2). The richest content of Fe was identified in parsley roots, followed by carrot roots and onion, especially for vegetables grown in contaminated soil. $\mathrm{Zn}$ and Mn concentrations in parsley and carrot roots and onion are very closely as values one from another, richer in vegetables grown in contaminated soils, especially for the ones from $\mathrm{R}$ area. For parsley roots from $\mathrm{R}$ area, $\mathrm{Zn}$ concentration exceeds maximum allowable limit (MAL) in these vegetables. The highest concentration of $\mathrm{Cu}$ was detected also in parsley roots, when $\mathrm{Cu}$ concentration exceeds MAL. The $\mathrm{Cu}$ concentrations in parsley and carrot roots from reference area are higher than in onion. Generally, in vegetables from contaminated $\mathrm{M}$ area $\mathrm{Cu}$ concentrations are higher than in contaminated $\mathrm{R}$ area. The smallest $\mathrm{Ni}$ concentration was identified in onion. Parsley roots accumulate the highest concentration of $\mathrm{Ni}$ in contaminated areas. $\mathrm{Cd}$ and $\mathrm{Pb}$ are the most toxic heavy metals with very restrictive limits (Table 2). Meaningful Cd contents were identified only in vegetables from contaminated $\mathrm{R}$ area (especially parsley roots). $\mathrm{Pb}$ was identified in all vegetables from all areas. In reference area the $\mathrm{Pb}$ concentrations in all investigated vegetables are small and away of MAL. In contaminated areas $\mathrm{Pb}$ concentrations increase to MAL are exceeded by parsley and carrot roots, especially in $\mathrm{R}$ area (Table 2 ). The same results ( $\mathrm{Cu}$ between 1-4 $\mathrm{mg} \mathrm{Kg}^{-1}$, $\mathrm{Zn}$ between 10-50 $\mathrm{mg} \mathrm{Kg}^{-1}$, $\mathrm{Cd}$ between 0.1-0.27 $\mathrm{mg} \mathrm{Kg}^{-1}$ and $\mathrm{Pb}$ between 1-5.5 mg $\mathrm{Kg}^{-1}$ fresh matter) were obtained in root vegetables grown in contaminated areas from Copsa Mica, Zlatna and Baia Mare [12]. These regions from Romania are well recognized like anthropogenic contaminated areas with heavy metals [12-16].

Like in root vegetables, Fe is the predominant metal in leafy vegetables in the both samples from contaminated and reference sites (Table 3). The highest concentrations were identified in parsley leaves followed by cabbage, carrot leaves and lettuce, especially in contaminated sites $\mathrm{R}$ and $\mathrm{M}$. In all leafy vegetables $\mathrm{Zn}$ and $\mathrm{Mn}$ are in the same range of concentrations. In contaminated sites $\mathrm{R}$ and $\mathrm{M}$ the concentrations of both metals are higher than in reference site. $\mathrm{Zn}$ concentration exceeded the

Table 2 Heavy metals contents in root vegetables and onion from investigated areas $\left(\mathrm{mgKg}^{-1}\right.$ fresh matter, $\left.{ }^{*} \mathrm{p}<0.05\right)$

\begin{tabular}{|c|c|c|c|c|c|c|c|}
\hline $\begin{array}{l}\text { Vegetables/Metals content } \\
\pm \text { Standard Deviation }\end{array}$ & $\mathrm{Fe} \pm \mathrm{SD}$ & $M n \pm S D$ & $\mathrm{Zn} \pm \mathrm{SD}$ & $\mathrm{Cu} \pm \mathrm{SD}$ & $\mathrm{Ni} \pm \mathrm{SD}$ & $C d \pm S D$ & $\mathrm{~Pb} \pm \mathrm{SD}$ \\
\hline Parsley Root (R) & $221.80^{*} \pm 40.69$ & $37.83^{*} \pm 13.01$ & $45.82^{*} \pm 17.59$ & $5.66^{*} \pm 1.14$ & $1.28^{*} \pm 0.72$ & $0.20^{*} \pm 0.12$ & $15.78^{*} \pm 7.81$ \\
\hline Parsley Root(M) & $99.02 \pm 25.84$ & $8.10^{*} \pm 2.34$ & $7.74^{*} \pm 1.59$ & $6.88^{*} \pm 0.86$ & $0.49 \pm 0.08$ & $0.04 \pm 0.02$ & $0.66^{*} \pm 0.21$ \\
\hline Parsley Root (Ref) & $48.78 \pm 15.29$ & $3.27 \pm 0.79$ & $3.52 \pm 0.98$ & $1.22 \pm 0.35$ & $0.19 \pm 0.05$ & $0.01 \pm 0.00$ & $0.08 \pm 0.01$ \\
\hline Carrot Root(R) & $29.97^{*} \pm 5.72$ & $3.06^{*} \pm 0.25$ & $4.93^{*} \pm 1.06$ & $1.54^{*} \pm 0.21$ & $0.18^{*} \pm 0.01$ & $0.08^{*} \pm 0.02$ & $2.11^{*} \pm 0.52$ \\
\hline Carrot Root (M) & $31.89^{*} \pm 2.51$ & $2.22 \pm 0.40$ & $3.18 \pm 0.44$ & $1.77^{*} \pm 0.23$ & $0.08 \pm 0.02$ & $0.03 \pm 0.00$ & $0.09 \pm 0.01$ \\
\hline Carrot Root (Ref) & $17.31 \pm 1.70$ & $1.43 \pm 0.18$ & $2.05 \pm 0.16$ & $0.74 \pm 0.08$ & $0.04 \pm 0.01$ & $0.01 \pm 0.00$ & $0.06 \pm 0.02$ \\
\hline Onion (R) & $15.26^{*} \pm 2.24$ & $4.07^{*} \pm 0.52$ & $10.91^{*} \pm 1.82$ & $0.43 \pm 0.24$ & $0.21^{*} \pm 0.03$ & $0.06^{*} \pm 0.01$ & $0.50^{*} \pm 0.15$ \\
\hline Onion (M) & $4.65 \pm 2.20$ & $1.34^{*} \pm 0.59$ & $2.01^{*} \pm 0.97$ & $1.37^{*} \pm 0.14$ & $0.03 \pm 0.01$ & $0.01 \pm 0.00$ & $0.13^{*} \pm 0.05$ \\
\hline Onion (Ref) & $1.56 \pm 0.28$ & $0.32 \pm 0.05$ & $0.78 \pm 0.08$ & $0.25 \pm 0.01$ & $0.01 \pm 0.00$ & $0.01 \pm 0.00$ & $0.04 \pm 0.03$ \\
\hline $\begin{array}{l}\text { Maximum allowable } \\
\text { limits (MAL) }\end{array}$ & - & - & 15.00 & 5.00 & - & 0.10 & 0.50 \\
\hline
\end{tabular}


Table 3 Heavy metals contents in leafy vegetables from investigated areas $\left(\mathrm{mg} \mathrm{Kg}^{-1}\right.$ fresh matter, $\left.* \mathbf{p}<0.05\right)$

\begin{tabular}{lccccccc}
\hline $\begin{array}{l}\text { Vegetables/Metals content } \\
\pm \text { Standard Deviation }\end{array}$ & Fe \pm SD & Mn \pm SD & Zn \pm SD & Cu \pm SD & Ni \pm SD & Cd \pm SD & Pb \pm SD \\
\hline Carrot Leaf (R) & $31.59 \pm 5.62$ & $3.13 \pm 0.64$ & $3.77^{*} \pm 0.81$ & $0.40 \pm 0.08$ & $0.17 \pm 0.02$ & $0.01 \pm 0.00$ & $0.20^{*} \pm 0.07$ \\
Carrot Leaf (M) & $51.45^{*} \pm 7.48$ & $5.57^{*} \pm 0.40$ & $5.61 \pm 0.40$ & $2.12^{*} \pm 0.18$ & $0.38^{*} \pm 0.09$ & $0.04 \pm 0.00$ & $0.12 \pm 0.02$ \\
Carrot Leaf (Ref) & $14.25 \pm 1.75$ & $1.38 \pm 0.09$ & $1.36 \pm 0.36$ & $0.29 \pm 0.02$ & $0.11 \pm 0.02$ & $0.01 \pm 0.00$ & $0.03 \pm 0.00$ \\
Parsley Leaf (R) & $104.03 \pm 26.52$ & $7.32 \pm 1.56$ & $9.39 \pm 1.21$ & $1.77 \pm 0.11$ & $0.38^{*} \pm 0.02$ & $0.09 \pm 0.01$ & $1.97^{*} \pm 0.27$ \\
Parsley Leaf (M) & $106.75^{*} \pm 13.63$ & $9.72^{*} \pm 1.55$ & $10.44 \pm 2.16$ & $4.79^{*} \pm 0.75$ & $1.87^{*} \pm 0.19$ & $0.05 \pm 0.01$ & $0.50 \pm 0.08$ \\
Parsley Leaf (Ref) & $73.17 \pm 5.51$ & $5.88 \pm 0.65$ & $9.13 \pm 2.45$ & $1.03 \pm 0.27$ & $0.30 \pm 0.11$ & $0.03 \pm 0.01$ & $0.28 \pm 0.07$ \\
Cabbage (R) & $60.11^{*} \pm 6.34$ & $10.47^{*} \pm 1.46$ & $16.30^{*} \pm 3.74$ & $1.36^{*} \pm 0.15$ & $0.70^{*} \pm 0.11$ & $0.12 \pm 0.02$ & $0.90^{*} \pm 0.30$ \\
Cabbage (M) & $31.53 \pm 15.54$ & $9.15^{*} \pm 4.24$ & $8.51 \pm 4.55$ & $2.77^{*} \pm 0.90$ & $0.33 \pm 0.18$ & $0.06 \pm 0.03$ & $0.25 \pm 0.16$ \\
Cabbage (Ref) & $16.06 \pm 2.95$ & $3.85 \pm 0.80$ & $3.28 \pm 0.63$ & $0.45 \pm 0.10$ & $0.13 \pm 0.03$ & $0.01 \pm 0.00$ & $0.05 \pm 0.01$ \\
Lettuce (R) & $35.88^{*} \pm 4.36$ & $8.33^{*} \pm 1.32$ & $14.46^{*} \pm 2.77$ & $1.86 \pm 0.27$ & $0.28^{*} \pm 0.04$ & $0.09 \pm 0.01$ & $0.62^{*} \pm 0.12$ \\
Lettuce (M) & $16.90 \pm 2.55$ & $4.12 \pm 0.60$ & $5.14 \pm 0.80$ & $2.22^{*} \pm 0.40$ & $0.18 \pm 0.03$ & $0.09 \pm 0.01$ & $0.21 \pm 0.11$ \\
Lettuce (Ref) & $13.60 \pm 1.40$ & $3.46 \pm 0.55$ & $5.32 \pm 0.68$ & $0.76 \pm 0.15$ & $0.10 \pm 0.03$ & $0.02 \pm 0.00$ & $0.08 \pm 0.02$ \\
Maximum allowable limits (MAL) & - & - & $\mathbf{1 5}$ & $\mathbf{5}$ & - & $\mathbf{0 . 2 0}$ & $\mathbf{0 . 5 0}$ \\
\hline
\end{tabular}

MAL in cabbage from $\mathrm{R}$ site. $\mathrm{Cu}$ content in leafy vegetables is higher in samples from $\mathrm{M}$ contaminated site and, in parsley leaves is very close to maximum allowable limits. In the leafy vegetables $\mathrm{Ni}$ contents are in the same range of concentrations like copper, superior in vegetables from contaminated sites $R$ and $M(p<0.05)$. $\mathrm{Cd}$ contents are significantly higher in contaminated sites $\mathrm{R}$ and $\mathrm{M}$, especially in cabbage, lettuce and parsley leaves, but not exceeded the MAL $\left(0.2 \mathrm{mg} \mathrm{Kg}^{-1}\right.$ fresh matter). Leafy vegetables from contaminated sites have $\mathrm{Pb}$ content higher than normal values especially for site $\mathrm{R}$ when the $\mathrm{Pb}$ values come to exceeded MAL in parsley leaves, cabbage and lettuce. In leafy vegetables grown in contaminated areas from Middle and North of Romania (Copsa Mica, Zlatna and Baia Mare) were identified also very high concentrations of $\mathrm{Cd}\left(2-10 \mathrm{mg} \mathrm{Kg}^{-1}\right.$ dry matter) and $\mathrm{Pb}$ (40-250 $\mathrm{mg} \mathrm{Kg}^{-1}$ dry matter), especially in lettuce and parsley leaves [12]. Leafy vegetables are recognized as well as heavy metals accumulators in contaminated soils and also in irrigated soil with waste water. In these conditions these plants (especially lettuce) accumulate $\mathrm{Cd}$ and $\mathrm{Pb}$ in concentrations higher than MAL $[6,7,9]$. In experimental pods with contaminated soil from industrial area and fertilizers, a high transfer ratio from soil to plant (especially for $\mathrm{Cd}$ ) and high exceeding of the maximum admitted values (over 200 times for fertilized and over 100 times for unfertilized cases) for heavy metals (especially $\mathrm{Cd}$ and $\mathrm{Pb}$ ) in lettuce were observed [24].

In fruit vegetables (Table 4) the higher concentrations of Fe (the major metal), $\mathrm{Zn}$ and Mn (as second metals), were identified in green beans especially in contaminated sites. Cucumber plants accumulate lower Fe but more $\mathrm{Mn}, \mathrm{Zn}$ and $\mathrm{Cu}$ in contaminated sites comparatively with reference site and higher concentrations of $\mathrm{Cd}$ and $\mathrm{Pb}$ which exceeded MAL, especially in $\mathrm{R}$ site. Also in edible part of cucumber plants grown in contaminated areas from Copsa Mica, Zlatna and Baia

Table 4 Heavy metals contents in fruit vegetables from investigated areas $\left(\mathrm{mgKg}^{-1}\right.$ fresh matter, $\left.{ }^{*} \mathbf{p}<0.05\right)$

\begin{tabular}{|c|c|c|c|c|c|c|c|}
\hline $\begin{array}{l}\text { Vegetables/Metals content } \\
\pm \text { Standard Deviation }\end{array}$ & $\mathrm{Fe} \pm \mathrm{SD}$ & $M n \pm S D$ & $\mathrm{Zn} \pm \mathrm{SD}$ & $\mathrm{Cu} \pm \mathrm{SD}$ & $\mathrm{Ni} \pm \mathrm{SD}$ & $C d \pm S D$ & $\mathrm{~Pb} \pm \mathrm{SD}$ \\
\hline Carrot Leaf (R) & $31.59 \pm 5.62$ & $3.13 \pm 0.64$ & $3.77^{*} \pm 0.81$ & $0.40 \pm 0.08$ & $0.17 \pm 0.02$ & $0.01 \pm 0.00$ & $0.20^{*} \pm 0.07$ \\
\hline Carrot Leaf (M) & $51.45^{*} \pm 7.48$ & $5.57^{*} \pm 0.40$ & $5.61 \pm 0.40$ & $2.12^{*} \pm 0.18$ & $0.38^{*} \pm 0.09$ & $0.04 \pm 0.00$ & $0.12 \pm 0.02$ \\
\hline Carrot Leaf (Ref) & $14.25 \pm 1.75$ & $1.38 \pm 0.09$ & $1.36 \pm 0.36$ & $0.29 \pm 0.02$ & $0.11 \pm 0.02$ & $0.01 \pm 0.00$ & $0.03 \pm 0.00$ \\
\hline Parsley Leaf (R) & $104.03 \pm 26.52$ & $7.32 \pm 1.56$ & $9.39 \pm 1.21$ & $1.77 \pm 0.11$ & $0.38^{*} \pm 0.02$ & $0.09 \pm 0.01$ & $1.97^{*} \pm 0.27$ \\
\hline Parsley Leaf (M) & $106.75^{*} \pm 13.63$ & $9.72^{*} \pm 1.55$ & $10.44 \pm 2.16$ & $4.79^{*} \pm 0.75$ & $1.87^{*} \pm 0.19$ & $0.05 \pm 0.01$ & $0.50 \pm 0.08$ \\
\hline Parsley Leaf (Ref) & $73.17 \pm 5.51$ & $5.88 \pm 0.65$ & $9.13 \pm 2.45$ & $1.03 \pm 0.27$ & $0.30 \pm 0.11$ & $0.03 \pm 0.01$ & $0.28 \pm 0.07$ \\
\hline Cabbage (R) & $60.11^{*} \pm 6.34$ & $10.47^{*} \pm 1.46$ & $16.30^{*} \pm 3.74$ & $1.36^{*} \pm 0.15$ & $0.70^{*} \pm 0.11$ & $0.12 \pm 0.02$ & $0.90^{*} \pm 0.30$ \\
\hline Cabbage (M) & $31.53 \pm 15.54$ & $9.15^{*} \pm 4.24$ & $8.51 \pm 4.55$ & $2.77^{*} \pm 0.90$ & $0.33 \pm 0.18$ & $0.06 \pm 0.03$ & $0.25 \pm 0.16$ \\
\hline Cabbage (Ref) & $16.06 \pm 2.95$ & $3.85 \pm 0.80$ & $3.28 \pm 0.63$ & $0.45 \pm 0.10$ & $0.13 \pm 0.03$ & $0.01 \pm 0.00$ & $0.05 \pm 0.01$ \\
\hline Lettuce (R) & $35.88^{*} \pm 4.36$ & $8.33^{*} \pm 1.32$ & $14.46^{*} \pm 2.77$ & $1.86 \pm 0.27$ & $0.28^{*} \pm 0.04$ & $0.09 \pm 0.01$ & $0.62^{*} \pm 0.12$ \\
\hline Lettuce (M) & $16.90 \pm 2.55$ & $4.12 \pm 0.60$ & $5.14 \pm 0.80$ & $2.22^{*} \pm 0.40$ & $0.18 \pm 0.03$ & $0.09 \pm 0.01$ & $0.21 \pm 0.11$ \\
\hline Lettuce (Ref) & $13.60 \pm 1.40$ & $3.46 \pm 0.55$ & $5.32 \pm 0.68$ & $0.76 \pm 0.15$ & $0.10 \pm 0.03$ & $0.02 \pm 0.00$ & $0.08 \pm 0.02$ \\
\hline Maximum allowable limits (MAL) & - & - & 15 & 5 & - & 0.20 & 0.50 \\
\hline
\end{tabular}


Mare were identified $\mathrm{Pb}$ in concentrations that exceed MAL (0.6 mg Kg ${ }^{-1}$ fresh matter) and Cd around $0.1 \mathrm{mg}$ $\mathrm{Kg}^{-1}$ fresh matter [12]. Like in these studies for fruit vegetables remarkable differences between the heavy metals contents of rural areas (non contaminated areas), semi-urban and industrial areas $[10,25]$ were observed. In industrial areas $\mathrm{Ni}$ and $\mathrm{Zn}$ were reported in higher concentrations compared to control areas. In semiurban areas the concentrations of $\mathrm{Cu}$ in vegetables reported were 2-3 times higher than the rural areas. The increased values of $\mathrm{Pb}$ were determined in vegetables grown in industrial areas.

\section{Daily metals intakes estimate and Target Hazard Quotients}

Daily metals intakes estimate for each vegetable (edible part) are shown in Table 5.The highest $\mathrm{Fe}, \mathrm{Mn}$ and $\mathrm{Pb}$ intakes have corresponded to parsley roots from $\mathrm{R}$ area (66.54, 11.35 and respectively $4.735 \mathrm{mg} \mathrm{day}^{-1}$ person $\left.{ }^{-1}\right)$. These values exceeded upper tolerable daily intakes (UL) level (45.0, 11.0 and respectively $0.24 \mathrm{mg}^{-1 a y}{ }^{-1}$ person $^{-1}$ ) established by the Institute of Medicine, for 19$>70$ years both male and female $[1,26]$. Values for $\mathrm{Zn}$, $\mathrm{Cu}, \mathrm{Ni}$ and $\mathrm{Cd}$ intakes are under $\mathrm{UL}$ for all vegetables. In $\mathrm{R}$ area, $\mathrm{Pb}$ exceeded the UL limit in the case of carrot roots and cabbage. Generally the dietary intakes of investigated metals $\mathrm{Fe}, \mathrm{Mn}, \mathrm{Zn}, \mathrm{Cu}, \mathrm{Ni}, \mathrm{Cd}$ and $\mathrm{Pb}$, from vegetables grown in contaminated areas $R$ and $M$ were above the dietary intakes of metals from reference area, and below the tolerable limits, with some exceptions (Table 5).

Target Hazard Quotients is a complex parameter used for the estimation of potential health risks associated with long term exposure to chemical pollutants [19-23].

Table 5 Daily metals intakes estimate (DImetal) for vegetables from investigated areas

\begin{tabular}{|c|c|c|c|c|c|c|c|}
\hline Vegetables/DImetal (mg day ${ }^{-1}$ person $^{-1}$ ) & $\mathrm{DI} \mathrm{Fe}$ & $\mathrm{DI} M \mathrm{n}$ & DI Zn & $\mathrm{DI} \mathrm{Cu}$ & $\mathrm{DI} \mathrm{Ni}$ & $\mathrm{DI} C d$ & $\mathrm{DI} \mathrm{Pb}$ \\
\hline UL (mg day ${ }^{-1}$ person $^{-1}$ ) & 45 & 11.00 & 40.00 & 10.000 & 1.000 & 0.064 & 0.240 \\
\hline Recommended Daily Intake (mg day ${ }^{-1}$ person $^{-1}$ ) & $8(18)$ & $2.3(1.8)$ & $11(8)$ & 0.900 & 0.500 & 0.000 & 0.00 \\
\hline \multicolumn{8}{|c|}{ Root vegetables and onion } \\
\hline Root parsley $R$ & 66.54 & 11.35 & 13.75 & 1.70 & 0.385 & 0.059 & 4.735 \\
\hline Root parsley M & 29.70 & 2.43 & 2.32 & 2.06 & 0.146 & 0.012 & 0.198 \\
\hline Root parsley Ref & 14.63 & 0.98 & 1.05 & 0.37 & 0.057 & 0.002 & 0.023 \\
\hline Root carrot $\mathrm{R}$ & 8.99 & 0.92 & 1.48 & 0.46 & 0.055 & 0.024 & 0.633 \\
\hline Root carrot M & 9.57 & 0.67 & 0.95 & 0.53 & 0.024 & 0.008 & 0.027 \\
\hline Root carrot Ref & 5.19 & 0.43 & 0.62 & 0.22 & 0.013 & 0.003 & 0.017 \\
\hline Onion R & 4.58 & 1.22 & 3.27 & 0.13 & 0.063 & 0.017 & 0.151 \\
\hline Onion M & 1.40 & 0.40 & 0.60 & 0.41 & 0.004 & 0.003 & 0.040 \\
\hline Onion Ref & 0.47 & 0.10 & 0.23 & 0.07 & 0.009 & 0.002 & 0.012 \\
\hline \multicolumn{8}{|c|}{ Leafy vegetables } \\
\hline Leaf parsley $R$ & 10.40 & 0.73 & 0.94 & 0.18 & 0.038 & 0.009 & 0.197 \\
\hline Leaf parsley M & 10.67 & 0.97 & 1.04 & 0.48 & 0.187 & 0.005 & 0.050 \\
\hline Leaf parsley Ref & 7.32 & 0.59 & 0.91 & 0.10 & 0.030 & 0.003 & 0.028 \\
\hline Leaf carrot $\mathrm{R}$ & 3.16 & 0.31 & 0.38 & 0.03 & 0.017 & 0.001 & 0.020 \\
\hline Leaf carrot M & 5.14 & 0.56 & 0.56 & 0.21 & 0.038 & 0.004 & 0.012 \\
\hline Leaf carrot Ref & 1.42 & 0.14 & 0.14 & 0.04 & 0.011 & 0.001 & 0.003 \\
\hline Cabbage R & 18.03 & 3.14 & 4.89 & 0.41 & 0.209 & 0.035 & 0.269 \\
\hline Cabbage M & 9.46 & 2.74 & 2.55 & 0.83 & 0.099 & 0.018 & 0.074 \\
\hline Cabbage Ref & 4.82 & 1.15 & 0.98 & 0.13 & 0.040 & 0.003 & 0.016 \\
\hline Lettuce R & 10.76 & 2.50 & 4.34 & 0.56 & 0.085 & 0.028 & 0.185 \\
\hline Lettuce M & 5.07 & 1.24 & 1.54 & 0.665 & 0.054 & 0.026 & 0.064 \\
\hline Lettuce Ref & 4.08 & 1.04 & 1.60 & 0.23 & 0.031 & 0.005 & 0.023 \\
\hline \multicolumn{8}{|c|}{ Fruit vegetables } \\
\hline Cucumber R & 0.72 & 2.02 & 2.69 & 0.29 & 0.083 & 0.039 & 0.215 \\
\hline Cucumber M & 0.72 & 1.80 & 0.42 & 0.72 & 0.162 & 0.046 & 0.110 \\
\hline Cucumber Ref & 0.51 & 0.14 & 0.28 & 0.14 & 0.068 & 0.009 & 0.049 \\
\hline Green Bean R & 17.66 & 2.12 & 3.97 & 0.32 & 0.146 & 0.019 & 0.104 \\
\hline Green Bean M & 8.00 & 2.03 & 3.05 & 0.43 & 0.157 & 0.020 & 0.058 \\
\hline Green Bean Ref & 6.36 & 1.33 & 2.90 & 0.09 & 0.065 & 0.009 & 0.020 \\
\hline
\end{tabular}


Values of this parameter for investigated metals and vegetables are presented in Figure 1, 2 and 3. Individual THQ values approach or surpass 1 only for $\mathrm{Pb}$ in parsley and carrot roots from $\mathrm{R}$ area (Figure 1). The contributions from all metals bring the combined THQ values to exceeded 1 for parsley roots from $\mathrm{R}$ area (10.47 for male and 10.91 for female), for parsley roots from $M$ area (1.21 for male and 1.39 for female) and for carrot roots from $\mathrm{R}$ area (1.50 for male and 1.59 for female).

Also in leafy vegetables (Figure 2), in cabbage and lettuce from $\mathrm{R}$ area, combined THQ for male and female approach or surpass 1 . In fruit vegetables (Figure 3 ) THQ values only approach 1 in cucumber and green beans from $\mathrm{R}$ area. In reference area all THQ for male or female and combined values were $<1$, and smaller for all vegetables that in contaminated $M$ or $R$ areas. In this clear area the heavy metals health risks through the food chain was of no consequences and safe generally assumed. In contaminated $\mathrm{M}$ area, with soil rich in copper especially (Table 1 ), it is possible that some vegetables (parsley) accumulate more copper (Table 2) and together with other heavy metals increase THQ values

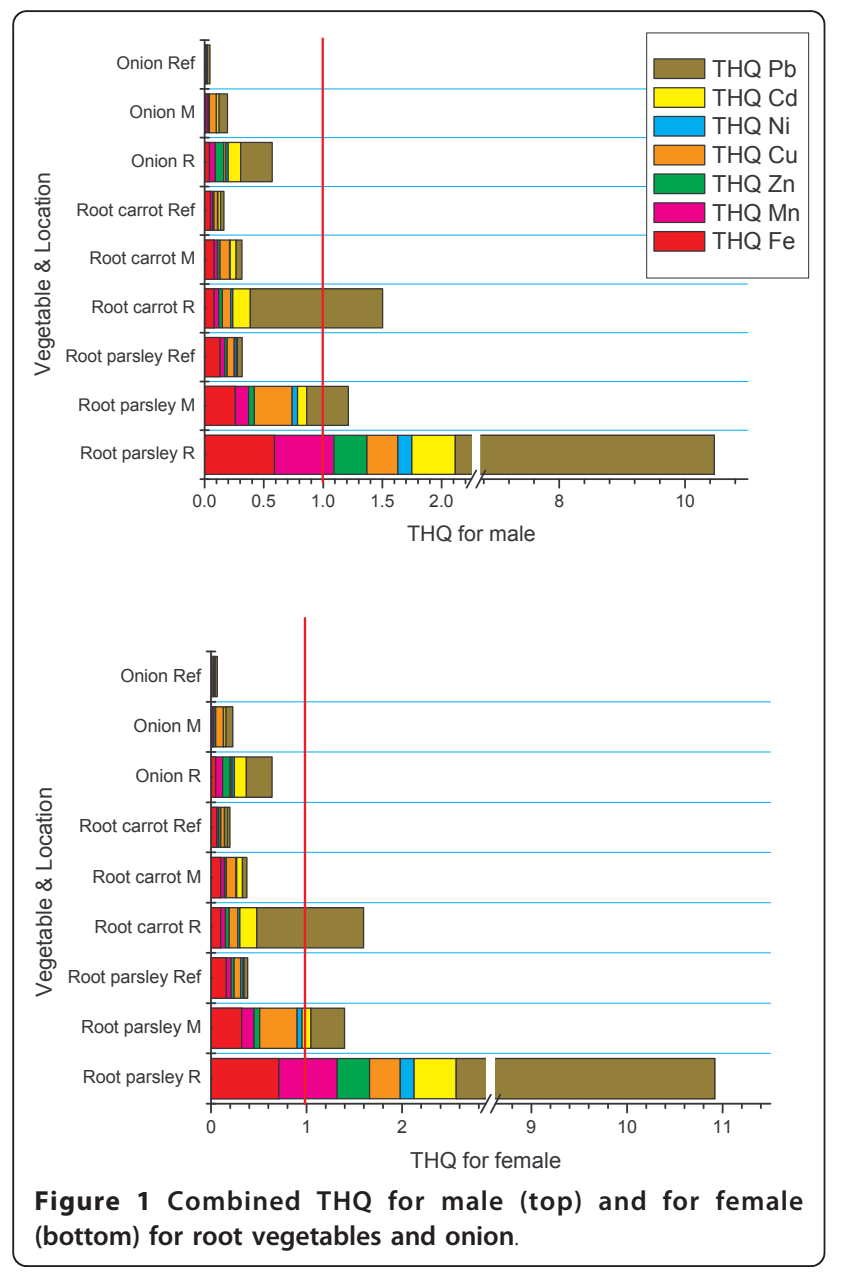

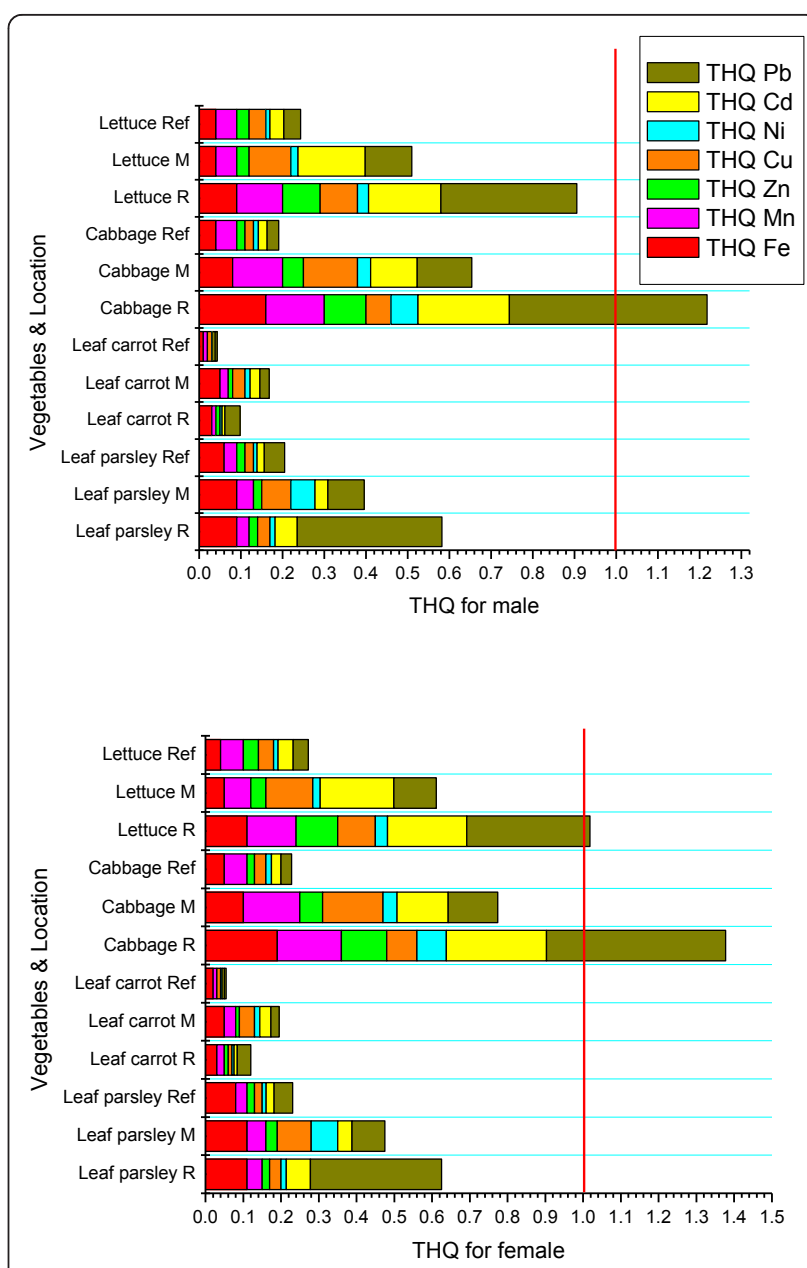

Figure 2 Combined THQ for male (top) and female (bottom) for leafy vegetables.

to a concern level (typically THQ $>1$ to $<5$ ). This situation was found more drastically in $\mathrm{R}$ area (Tables $1,2,3$ and 4), with soil rich especially in $\mathrm{Pb}(\mathrm{Pb}$ is a more toxic heavy metal than $\mathrm{Cu}$ ), where more vegetables (parsley, carrot, cabbage, lettuce, cucumber) accumulate in edible part (root and leaf) higher quantity from this metal surpassing MAL. In this way contribute substantially to rich combined THQ values to a level of concern (Figures 1,2) for parsley, carrot and cabbage.

The extremely toxic metal $\mathrm{Cd}$ was founded in contaminated soil in quantity that exceeded normal content from $\mathrm{R}$ area but under alert threshold values. In $\mathrm{M}$ and reference areas this extremely toxic heavy metal was founded in quantity that not exceeds normal content (Table 1). However due to high transfer coefficient of Cd from soil to some vegetables [24], it was found large amounts of $\mathrm{Cd}$ in parsley and cucumber in contaminated areas (Tables 2 and 4). These contaminated vegetables can raise the intake of $\mathrm{Cd}$ and contribute in a great share on the total value of THQ, especially for 

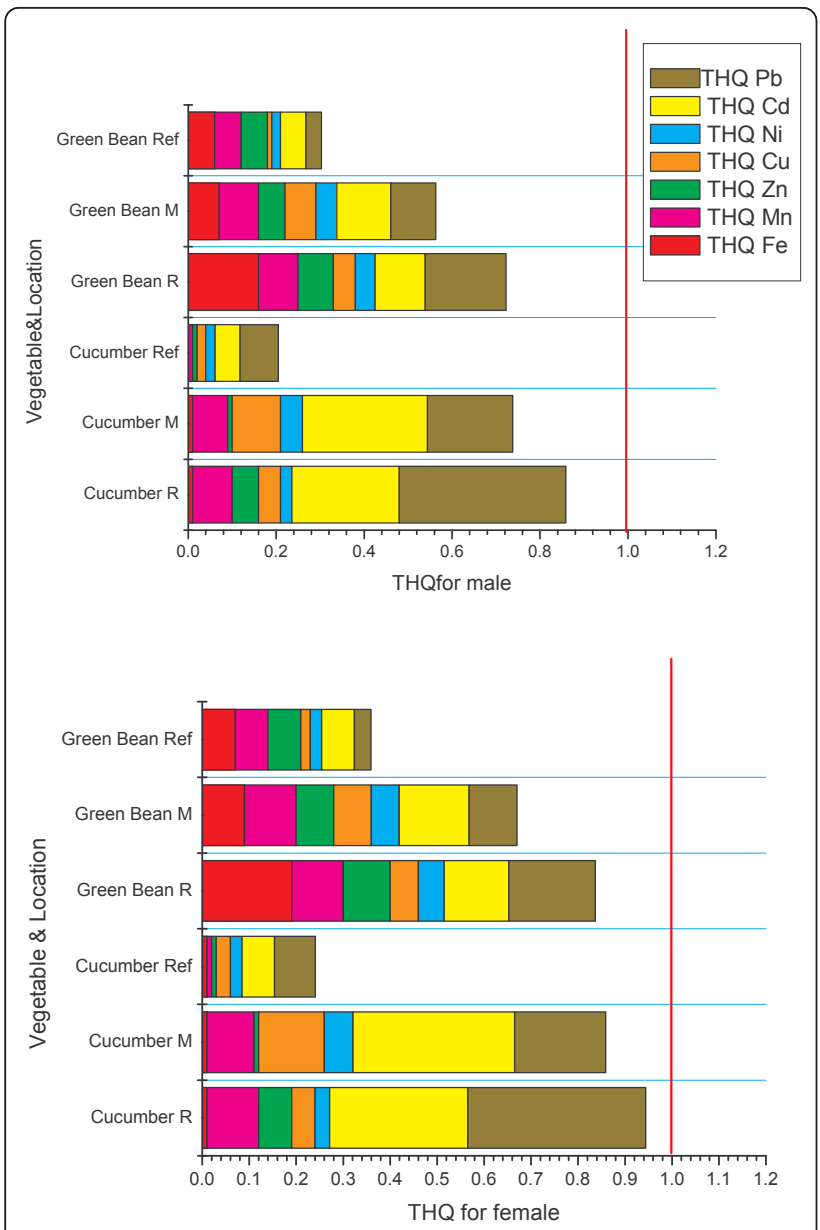

Figure 3 Combined THQ for male (top) and female (bottom) for fruit vegetables.

leafy and fruit vegetables grown in these areas, even if $\mathrm{Cd}$ content remains in the safe level (Figure 3) or exceed this level (Figure 2). More and more authors use successfully the THQ methodology to estimate the potential health risks associated with long term exposure to heavy metals from food crops irrigated with wastewater [6], vegetables from waste water irrigated area [7], wine [20], different beverage [21], seafood [22], vegetables grown in industrial and semi-urban areas [25] and dietary supplements [26]. Our results will supplement this information with data on vegetables grown in contaminated areas from long mining activities.

\section{Conclusion}

High levels of potentially hazardous metals are frequently found in vegetables originating from long mining activities areas, with high levels of contaminated soils as those studied in this case. The consumption of normal quantity of vegetables daily, some of them vegetables especially parsley, carrot, cabbage, lettuce and green beans give high combined THQ values and may present detrimental health concerns through a lifetime based on the metals contents alone. The findings of this study regarding metals contents in vegetables, DImetal and THQ suggest that the consumption of these vegetables grown in these areas is not free of risks. THQ parameter used in health risk assessment of heavy metals provides a better picture than using a simple parameter as content of metals from soils and vegetables. Further researches in this area will be warranted for the interests of public health, mainly to determine the mechanisms of metals absorption/inclusion during vegetables production. Also will be studied the agricultural techniques able to reduce heavy metals translocation in vegetables. These studies should include the influence of vegetable's varieties and seasonal variations, soil type and local customs. On the other hand, with food intake, in addition to vegetables, a significant proportion is represented by dairy products, meat and bread, water and other beverages, which may contribute to increase values of metals intakes and THQ. There are in these contaminated areas other sources of metal exposures such as dust inhalation, dermal contact and ingestion (for children) of metals-contaminated soils. All these may increase metals intakes and but were not included in this study.

\section{Experimental}

\section{Experimental site}

The study areas are located in South West of Romania, in the region named Banat County [27] (Figure 4). These areas have a continental-mediterranean climate, characterized by wide seasonal variations in annual rainfall $(700-900 \mathrm{~mm})$, cold and dry winters, and hot summers. The soils in these areas are mainly Alluvial Soils and Brown Redish types. By anthropic actions, these natural soils have becoming urban soils as Urbic Regosols, Regosols and Mixic Entiantrosols. The food vegetables are mainly: parsley (Petroselinum crispum), carrot (Daucus carota), onion bulb (Allium cepa), lettuce (Lactuca sativa), cucumber (Cucumis sativa), cabbage (Brasssica oleracea var. capitata) and green beans (Phaseolus vulgaris) [28]. Soil and vegetable samples were collected from familiarly farms located in two contaminated areas and one reference area. First contaminated area $(R)$ is located around Ruschita village which is the mining centre of the massif Poiana Rusca. This place has crystalline schist, limestone and sandstone rich in zinc, copper and especially lead. Second contaminated area (M) is located around Moldova Noua city. This is the biggest mine from the West of Romania and represents the second largest copper reserve, having estimated around 500 million tonnes of ore grading $0.35 \%$ copper [17]. The reference area, Borlova village, near 


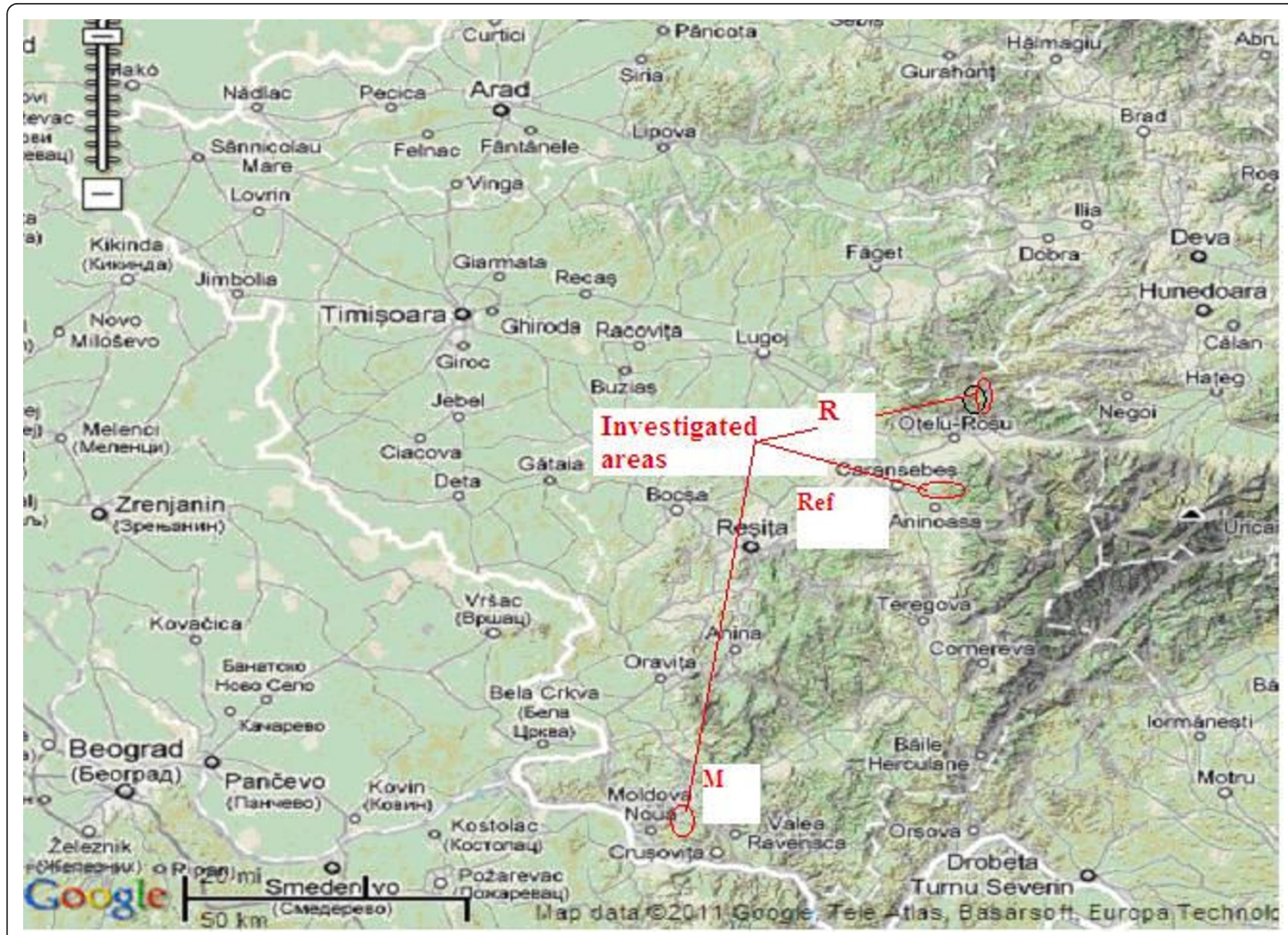

Figure 4 Map of experimental sites (processed after [27]).

Caransebes city, is located on the Sebes valley, at the foot of massif Muntele Mic, a nonpolluted area with less industry. In each area ( $R, M$ and Ref) were collected 8 soil samples, from the $0-20 \mathrm{~cm}$ depth of the A horizon and the same number and type of vegetables. Edible parts of vegetables were collected from the investigated zones inhabitant's gardens: root vegetables included parsley roots, carrot roots and bulb onions; leafy vegetables included parsley leaves, carrot leaves, cabbage and lettuce; fruit vegetables included cucumber and green beans. These are major vegetables grown in the experimental areas for own consumption of the inhabitants and for supply to retail and wholesale local markets.

\section{Samples collection and preparation}

Soil samples were air dried, crushed, passed through a 2 $\mathrm{mm}$ mesh sieve and stored at ambient temperature for analysis. All the collected samples of various vegetables were washed with double distilled water to remove airborne and soil pollutants. After washing, vegetable samples were oven dried at $80^{\circ} \mathrm{C}$ to constant weight. The dried samples were ground, passed through a $2 \mathrm{~mm}$ sieve and stored at room temperature before analysis.

Passing out of total metals content from soil to solution can realized by wet proceeding which consists in treating soil samples with mixture of mineral acids $\left(\mathrm{HCl}, \mathrm{HNO}_{3}, 3: 1\right.$ ratio) adapted after method 3050B of the United States Environmental Protection Agency [29]. The heavy metals contents in edible parts of vegetables were carried out in $\mathrm{HNO}_{3}$ solution resulted by plants ash digestion $[6,12]$. Each sample solution was made up with dilute $\mathrm{HNO}_{3}(0.5 \mathrm{~N})$ to a final volume of $50 \mathrm{~mL}$ and analyzed by flame atomic absorption spectrometry (FAAS) in University Environmental Research Test Laboratory. Necessary dilutions were made.

\section{Metals analysis and quality control}

The concentrations of $\mathrm{Fe}, \mathrm{Mn}, \mathrm{Zn}, \mathrm{Cu}, \mathrm{Ni}, \mathrm{Cd}$ and $\mathrm{Pb}$ in the filtrate were determined by using flame atomic absorption spectrophotometer with high resolution continuum source (Model ContrAA 300, Analytik Jena, Germany), fitted with a specific conditions of particular metal using appropriate drift blanks. Mix standard 
solutions of heavy metals (1000 mg/L), namely iron (Fe), manganese $(\mathrm{Mn})$, zinc $(\mathrm{Zn})$, copper $(\mathrm{Cu})$, nickel $(\mathrm{Ni})$, cadmium (Cd), and lead (Pb)- ICP Multielement Standard solution IV CertiPUR, were procured from Merck. Solutions of varying concentrations were prepared for all the metals by diluting the standards. Doubly distilled water (spectroscopic pure) was used for the preparation of reagents and standards. All chemicals were trace metal grade (Suprapur). Concentrate nitric acid $\left(\mathrm{HNO}_{3}\right.$ $65 \%)$, and concentrate $\mathrm{HCl}(30 \%)$, were obtained from Merck Germany. All glassware was treated with Pierce solution $20 \%(\mathrm{v} / \mathrm{v})$, rinsed with cold tap water followed by $20 \%(\mathrm{v} / \mathrm{v})$ nitric acid and then rinsed with double-distilled water. For quality control purposes, blanks and duplicates samples were analyzed during the procedure. NCS Certified Reference Material-DC 85104a and 85105a (China National Analysis Center for Iron\&Steel), was analyzed for quality assurance. Percent recovery means were: Fe (92\%), Mn (95\%), Zn (102\%), Cu (105\%), $\mathrm{Ni}(99 \%), \mathrm{Pb}(94 \%), \mathrm{Cd}(105 \%)$. The variation coefficients were below 10\%. Detection limits $(\mu \mathrm{g} / \mathrm{g})$ were determined by the calibration curve method: Fe (0.15), Mn (0.19), Zn (0.43), Cu (0.13), Ni (0.14), Cd (0.01), Pb (0.05). The blank reagent and standard reference soil materials were included in each sample batch to verify the accuracy and precision of the digestion procedure and also for subsequent analyses.

The data were statistically analyzed using a statistical package Origin 7 . The measures of metals content in soils and plants were expressed in terms of means and standard deviation, and the figures with the mean values. Statistical significance was computed using PairSamples T-Test, with a significance level of $\mathrm{p}<0.05$.

\section{Daily metals intakes estimate (DImetal)}

From our interview in the investigated areas from Banat County, one portion of $0.300 \mathrm{Kg}$ was considered a typical serving for a day of root vegetables (parsley, carrot or onion) or fruit vegetables (cucumber or green beans) and leafy vegetables (cabbage or lettuce) and $0.100 \mathrm{Kg}$ was considered a typical serving for a day of parsley or carrot leaves. The daily metals intakes estimate of Fe, $\mathrm{Mn}, \mathrm{Zn}, \mathrm{Cu}, \mathrm{Ni}, \mathrm{Pb}$ and $\mathrm{Cd}$ from each vegetable were calculated by multiplying the daily intake (estimated from local interview) by the metals concentrations determined in this study. The DImetal were compared with the upper tolerable daily intakes for metals (UL) $[1,19,26]$.

\section{Target Hazard Quotients (THQ)}

THQ is calculated by the general formula established by the EPA [19] using equation 1:
Table 6 Oral reference doses (RfD) and upper tolerable daily intakes (UL) for investigated metals.

\begin{tabular}{llll}
\hline $\mathbf{N r}$ & Element & $\mathbf{R f D}\left(\mathbf{m g ~ K g}^{-\mathbf{1}}\right.$ day $\left.^{\mathbf{- 1}}\right)$ [references] & $\begin{array}{l}\text { UL (mg day } \\
\text { [references] }\end{array}$ \\
\hline 1 & $\mathrm{Fe}$ & $0.700[31]$ & $45[1]$ \\
2 & $\mathrm{Mn}$ & $0.014[31]$ & $11[1]$ \\
3 & $\mathrm{Zn}$ & $0.300[6,31]$ & $40[1]$ \\
4 & $\mathrm{Cu}$ & $0.040[6,31]$ & $10[1]$ \\
5 & $\mathrm{Ni}$ & $0.020[6,31]$ & $1[1]$ \\
6 & $\mathrm{Cd}$ & $0.001[6,31]$ & $0.064[26]$ \\
7 & $\mathrm{~Pb}$ & $0.0035[6]$ & $0.240[26]$
\end{tabular}

The average body weight for people from Banat County [32]: Wmale $=81 \mathrm{Kg}$ and Wfemale $=67 \mathrm{Kg}$

$$
\mathrm{THQ}=\mathrm{E}_{\mathrm{F}} \mathrm{FF}_{\mathrm{D}} \mathrm{xDIM} / \mathrm{RfDxWxT}
$$

(See Additional file 1: THQ, male and female for investigated vegetables)

Where, $E_{F}$ is exposure frequency; $F_{D}$ is the exposure duration, DIM is the daily metal ingestion $\left(\mathrm{mg} \mathrm{person}^{-1}\right.$ day $^{-1}$ ) and RfD is the oral reference dose ( $\mathrm{mg} \mathrm{Kg}^{-1}$ day $\left.{ }^{1}\right)$; W is the average body weight $(\mathrm{Kg})$ and $\mathrm{T}$ is the average exposure time for noncarcinogens (365 days year ${ }^{-1}$ $x$ number of exposure years). For this project $E_{F}$ was set up at 183.5 days year $^{-1}$; in this area from Banat County peoples eat vegetable from own garden only 6 months yaer $^{-1}$. Length of exposure $\left(F_{D}\right)$ was set to 63 for males and 70 for females based on the average life expectancy, starting from 8 years of age [30].

DIM = Daily fresh food ingestion $\left(K_{g}\right.$ person $^{-1}$ day $\left.^{-1}\right)$ $\times$ Metal content $\left(\mathrm{mg} \mathrm{Kg}^{-1}\right.$ fresh matter). The used oral reference doses (RfD) and upper tolerable daily intakes for metals (UL) are presented in Table 6.

\section{Additional material}

Additional file 1: THQ, male and female for investigated vegetables.

\section{Acknowledgements}

We are grateful to the CNCSIS Romania for the financial support, Grant CISPPA Nr. 52157/1.10.2008 and our colleagues PhD Gabriel Mandru Heghedus, PhD Adrian Rivis and PhD Contantin Mateescu for permission to use statistical package Origin 7 and technical assistance.

\section{Authors' contributions}

$\mathrm{MH}, \mathrm{LMA}, \mathrm{DMB}, \mathrm{IG}$ and $\mathrm{IG}^{*}$ contributed equally to the study design, collection of data, development of the soil and vegetables sampling, analyses, interpretation of results and preparation of the paper. All authors read and approved the final manuscript.

\section{Competing interests}

The authors declare that they have no competing interests.

Received: 16 July 2011 Accepted: 22 October 2011 Published: 22 October 2011 


\section{References}

1. FDA (Food and Drug Administration): Dietary Reference Intakes for Vitamin A, Vitamin K, Arsenic, Boron, Chromium, Copper, lodine, Iron, Manganese, Molybdenum, Nickel, Silicon, Vanadium, and Zinc. Report of the Panel on Micronutrients. National AcademyPress, Washington, DC, Food and Drug Administration. Dietary supplements. Center for Food Safety and Applied Nutrition; 2001

2. Singh V, Garg AN: Availability of essential trace elements in Indian cereals, vegetables and spices using INAA and the contribution of spices to daily dietary intake. Food Chem 2006, 94:81-89.

3. Powers KM, Smith-Weller T, Franklin GM, Longstreth WT, Swanson PD, Checkoway $\mathrm{H}$ : Parkinson's disease risks associated with dietary iron, manganese, and other nutrient intakes. Neurology 2003, 60:1761-1766.

4. Llobet JM, Falco' G, Casas C, Teixido' A, Domingo JL: Concentration of arsenic, cadmium, mercury, and lead in common foods and estimated daily intake by children, adolescents, adults, and seniors of Catalonia, Spain. J Agric Food Chem 2003, 51:838-842.

5. Ikem A, Egiebor NO: Assessment of trace elements in canned fishes (mackerel, tuna, salmon, sardines and herrings) marketed in Georgia and Alabama (United States of America). J Food Comp Anal 2005, 18:771-787.

6. Khan S, Cao Q, Zheng YM, Huang YZ, Zhu YG: Health risks of heavy metals in contaminated soils and food crops irrigated with wastewater in Beijing, China. Environ Pollut 2008, 152:686-692.

7. Singh A, Sharma RK, Agrawal M, Marshall FM: Risk assessment of heavy metal toxicity through contaminated vegetables from waste water irrigated area of Varanasi, India. Tropical Ecology 2010, 51(2S):375-387.

8. Cui YJ, Zhu YG, Zhai R, Huang Y, Qiu Y, Liang J: Exposure to metal mixtures and human health impacts in a contaminated area in Nanning China. Environ Int 2005, 31:784-790.

9. Liu WH, Zhao JZ, Ouyang ZY, Soderlund L, Liu GH: Impacts of sewage irrigation on heavy metals distribution and contamination in Beijing, China. Environ Int 2005, 31:805-812.

10. Yang QW, Li H, Long FY: Heavy metals of vegetables and soils of vegetable bases in Chongqing, southwest China. Environ Monit Assess 2007, 130:271-279.

11. Cârlig ED, Macoveanu M: Quality analysis of the soils in the Cordun metallurgical platform area. EEMJ 2008, 7:851-858.

12. Lăcătuşu R, Lăcătuşu AR: Vegetable and fruits quality within heavy metals polluted areas in Romania. Carpth J of Earth and Environmental Science 2008, 3:115-129.

13. Damian F, Damian G, Lăcătuşu R, lepure G: Heavy metals concentration of the soils around Zlatna and Cop s a Mic ă smelters Romania. Carpath Journal of Earth and Environmental Science 2008, 3:65-82.

14. Secu CV, lancu OG, Buzgar N: Lead, zinc and copper in the bioaccumulative horizon of soils from la ş $\mathrm{i}$ and the surrounding areas. Carpath Journal of Earth and Environmental Science 2008, 3:131-144.

15. Lăcătuşu R, Cîtu G, Aston J, Lungu M, Lăcătuşu AR: Heavy metals soil pollution state in relation to potential future mining activities in the Roş ia Montană Area. Carpath Journal of Earth and Environmental Science 2009, 4:39-50.

16. Damian $G$, Damian $F$, Năsui $D$, Pop C, Pricop $C$ : The soils quality from the southern - eastern part of Baia Mare zone affected by metallurgical industry. Carpath Journal of Earth and Environmental Science 2010, 5:139-147

17. Steblez WG: The mineral industry of ROMANIA. U.S. Geological survey minerals Yearbook-1999;[http://minerals.usgs.gov/minerals/pubs/country/ 1999/9433099.pdf].

18. Gogoasa I, Oprea G, Gergen I, Alexa E, Cozma A, Bordean DM, Moigrădean D, Alda LM: Researches regarding the soil contamination with heavy metals in the Banat mountains. Journal of Agroalimentary Processes and Technologies 2009, 15:172-176.

19. United States. Environmental Protection Agency. Office of Wate Regulations and Standard: Guidance manual for assessing human health risks from chemically contaminated, fish and shellfish U.S. Environmental Protection Agency, Washington, D.C; 1989, EPA-503/8-89-002.

20. Naughton DP, Petróczi A: Heavy metal ions in wines: meta-analysis of target hazard quotients reveals health risks. Chem Centr J 2008, 2:22

21. Hague T, Petroczi A, Andrews PLR, Barker J, Naughton DP: Determination of metal ion content of beverages and estimation of target hazard quotients: a comparative study. Chem Centr J 2008, 2:13.
22. Petroczi A, Naughton DP: Mercury, cadmium and lead contamination in seafood: A comparative study to evaluate the usefulness of Target Hazard Quotients. Food Chem Toxicol 2009, 47:298-302

23. Khan S, Farooq R, Shahbaz S, Khan MA, Sadique M: Health Risk Assessment of Heavy Metals for Population via Consumption of Vegetables. World App/ Sci J 2009, 6:1602-1606.

24. Smical Al, Hotea V, Oros V, Juhasz J, Pop E: Studies on transfer and bioaccumulation of heavy metals from soil into lettuce. EEMJ 2008, 7:609-615

25. Srinivas N, Ramakrishna RS, Kumar SK: Trace metal accumulation in vegetables grown in industrial and semi-urban areas - a case study. Applied Ecology and Environmental Research 2009, 7:131-139.

26. Garcia-Rico L, Leyva-Perez J, Jara-Marini ME: Content and daily intake of copper, zinc, lead, cadmium, and mercury from dietary supplements in Mexico. Food Chem Toxicol 2007, 45:1599-1605.

27. Banat Map. [http://www.travelblog.org/Europe/Romania/Banat/map-banat. html]

28. Geographical description. [http://en.wikipedia.org/wiki/Banat]

29. USEPA (1996). United States environmental protection agency, method 3050B: Acid digestion of sediments, sludges, soils, \& oils. SW-846 Washington, DC: USEPA;[http://www.epa.gov/osw/hazard/testmethods/ sw846/pdfs/3050b.pdf].

30. Average life expectancy. [http://data.worldbank.org/romanian]

31. US EPA Human Health Risk Assessment: Risk-Based Concentration Table. [http://www.epa.gov/reg3hwmd/risk/human/rb-concentration_table/ Generic_Tables/index.htm]

32. Romanian Measurements. [http://www.slideshare.net/smihaialex/romanianmesurements].

doi:10.1186/1752-153X-5-64

Cite this article as: Harmanescu et al.: Heavy metals health risk assessment for population via consumption of vegetables grown in old mining area; a case study: Banat County, Romania. Chemistry Central Journal 2011 5:64.

\section{Publish with ChemistryCentral and every scientist can read your work free of charge \\ "Open access provides opportunities to our colleagues in other parts of the globe, by allowing anyone to view the content free of charge."} W. Jeffery Hurst, The Hershey Company.

- available free of charge to the entire scientific community

- peer reviewed and published immediately upon acceptance

- cited in PubMed and archived on PubMed Central

- yours - you keep the copyright

Submit your manuscript here:

http://www.chemistrycentral.com/manuscript/<smiles>c1ccccc1</smiles> 